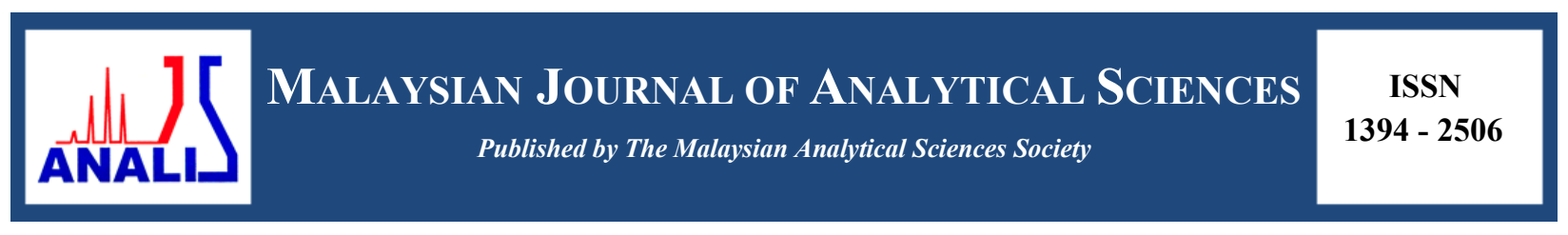

\title{
ASSESSMENT OF METALS CONCENTRATION IN TILAPIA (Oreochromis sp.) AND ESTIMATION OF DAILY INTAKE BY MALAYSIAN
}

\author{
(Penilaian Kepekatan Logam dalam Tilapia (Oreochromis sp.) dan Anggaran Pengambilan \\ Harian oleh Orang Malaysia) \\ Nurulnadia Mohd Yusoff ${ }^{1 *}$, Siti NurTahirah Jaafar ${ }^{1}$, Noor Azhar Mohamed Shazili ${ }^{2}$, \\ Nik Nurasyikin Nik Mohammad Azmi ${ }^{1}$, Mohamad Sofi Abu Hassan ${ }^{2}$ \\ ${ }^{I}$ School of Marine and Environmental Sciences \\ ${ }^{2}$ Institute of Oceanography and Environment \\ Universiti Malaysia Terengganu, 21030 Kuala Nerus, Terengganu, Malaysia \\ *Corresponding author: nurulnadia@umt.edu.my
}

Received: 13 December 2017; Accepted: 11 June 2018

\begin{abstract}
Aquaculture of tilapia is growing economically and nutritionally important in Malaysia. Fish is part of the human diet, the assessment of metals concentration in their tissues is compulsory. Cadmium $(\mathrm{Cd})$, copper $(\mathrm{Cu})$, lead $(\mathrm{Pb})$ and zinc $(\mathrm{Zn})$ concentrations were measured in the muscles, gills and liver tissue of tilapia, Oreochromis sp. Microwave digestion method was employed to extract the target metals followed by measurement of concentration by inductively coupled plasma-mass spectrometry (ICP-MS). The level of $\mathrm{Cd}, \mathrm{Cu}$ and $\mathrm{Pb}$ were significantly high $(\mathrm{p}<0.05)$ in the liver of tilapia from Tumpat lagoon with $0.359 \pm 0.129,71.1 \pm 31.3$ and $2.14 \pm 0.451 \mu \mathrm{g} / \mathrm{g}$ dry weight $(\mathrm{dw})$, respectively compared to the fish liver from Terengganu River. However, Zn concentration was significantly high in muscle tissues with $15.2 \pm 3.75 \mu \mathrm{g} / \mathrm{g}$ dw. Daily intake of metals in human was also estimated and compared to established standards. The intake levels of $\mathrm{Cd}, \mathrm{Cu}, \mathrm{Pb}$ and $\mathrm{Zn}$ were lower than the standards. Hence, tilapia is safe for consumption if they do not ingest the liver. Lipid peroxidation (LPO) activity was measured in the same tissue but the correlation values between level of metals and malondialdehyde (MDA) were inconsistent. Thus, further investigation in controlled environment such as laboratory exposure experiment is necessary.
\end{abstract}

Keywords: metal, daily intake, Tumpat, Terengganu, lipid peroxidation

\begin{abstract}
Abstrak
Kepentingan akuakultur tilapia dari segi ekonomi dan pemakanan semakin meningkat di Malaysia. Oleh kerana ikan adalah sebahagian daripada diet manusia, analisis kepekatan logam di dalam tisu tilapia perlu dilakukan. Kadmium $(\mathrm{Cd})$, kuprum $(\mathrm{Cu})$, plumbum $(\mathrm{Pb})$ dan zink $(\mathrm{Zn})$ telah diukur di dalam tisu otot, insang dan hati tilapia, Oreochromis sp. Kaedah pencernaan gelombang mikro telah digunakan untuk mengekstrak logam sasaran tersebut, dan diikuti dengan pengukuran kepekatan menggunakan spektrometri plasma-jisim berganding secara aruhan (ICP-MS). Tahap $\mathrm{Cd}, \mathrm{Cu}$ dan $\mathrm{Pb}$ di dalam hati tilapia dari lagun Tumpat ternyata tinggi ( $\mathrm{p}<0.05$ ) dengan bacaan masing-masing $0.359 \pm 0.129,71.1 \pm 31.3 \mathrm{dan} 2.14 \pm 0.451 \mu \mathrm{g} / \mathrm{g}$ berat kering $(\mathrm{dw})$ berbanding dengan hati ikan dari Sungai Terengganu. Walau bagaimanapun, kepekatan $\mathrm{Zn}$ ternyata tinggi $(\mathrm{p}<0.05)$ di dalam tisu otot iaitu $15.2 \pm 3.75 \mu \mathrm{g} / \mathrm{g}$ dw. Pengambilan logam harian oleh manusia juga telah dianggarkan dan dibandingkan dengan kadar piawaian yang ditetapkan. Kadar pengambilan $\mathrm{Cd}, \mathrm{Cu}, \mathrm{Pb}$ dan $\mathrm{Zn}$ didapati lebih rendah daripada piawaian, maka tilapia selamat untuk dimakan selagi mereka tidak memakan tisu hati. Aktiviti pemperoksidaan lipid (LPO) diukur dalam tisu yang sama tetapi nilai korelasi antara tahap logam dan malondialdehid (MDA) tidak konsisten. Oleh itu, kajian lanjut dalam persekitaran terkawal seperti eksperimen di makmal perlu dilakukan.
\end{abstract}

Kata kunci: logam, pengambilan harian, Tumpat, Terengganu, pemperoksidaan lipid 


\section{Introduction}

Tilapia is the second most farmed fish group worldwide. The production has quadrupled over the past decades due to their promising characteristics for aquaculture purpose, high marketability and relatively stable market prices [1]. Tilapia farmed fish in the world reported yielding over 3 million metric tons in 2009. Oreochromis spp. is one of the most commercially important in aquaculture production contributing to the figures reported [2]. In 2012, aquaculture production in Malaysia contributed 163,757 tons valued at RM992 million and the main cultures species were black and red tilapia, Oreochromis spp. Department of Fisheries (DOF) Malaysia also predicted with a growing population and preference for fish, the annual demand will increase from 1.7 million tons in 2011 to 1.93 million in 2020 [3]. To comply with the demand, DOF initiated Aquaculture Industrial Zone (AIZ) including aquaculture farm in the Tumpat lagoon and Terengganu River.

Tilapia is known to have high tolerance to crowding, disease resistance and wide range of salt tolerance [2, 4]. Therefore, they can be cultured in both seawater (Tumpat lagoon) and freshwater ecosystem (Terengganu River). Tumpat lagoon located in the north-east of Peninsular Malaysia, bordering between Thailand and northern Malaysia. The estimated aquaculture area is 500 x 200 meters, along Seri Tujoh Beach. DOF of Tumpat had banned the locals to purchase and consume shellfish products in 2015 due to outbreak of bacteria and pollution in Tumpat lagoon. Terengganu River is the longest river in Terengganu $(17 \mathrm{~km})$ with a semi-enclosed breakwater near the river mouth. Following the existence of breakwater, sand dredging activity is continuously operated and potentially causing embedded pollutant to emerge in particulate form. Beside breakwater, a draw bridge construction that began in 2014 is still ongoing and predicted to disturb the ecology as well as contaminating Terengganu River. Tilapias in both sites were cultured in extended period ( 3 to 6 months, personal communication) prior to sell; hence they could be a good bioindicator of pollution such as metals.

Metals are ubiquitous pollutants which commonly found in water, sediment, as well as living organisms such as fish [5]. Metal pollution generally increases with the human's technological achievement including sand dredging, agriculture, sewage and motor vehicle industry [6]. Fish assimilate metals through ingestion of particulate in water across the gill, dietary uptake and absorption into muscle tissues [7]. Metals are known to disturb the physiological and biochemical functions in rainbow trout, zebrafish and tilapia [8]. Besides, they are toxic to human in high concentration that lead to various implications such as diarrhea, dysfunctions in the kidneys and impairment of reproduction $[9,10]$. The increase demand of tilapia proportionally increases the quantity of consumption by local Malaysian, thus investigation of metals concentration in farmed tilapia is necessary.

Cheung et al. [11] and Wong et al. [12] have used tilapia tissues as biomarker of exposure to metal pollution in water which made tilapia a useful model fish species for ecotoxicological studies. Extraction of targeted elements was normally practiced in metals studies by using high-end instrument as measuring tools. However, these high-end instruments were both inefficiently time and cost consuming. Recently, the trend of monitoring the pollutant effects on animals was shifted towards molecular approach which represents better early signs of biological effects [13]. Metals can induce oxidative stress in aquatic animals by disturbing antioxidant efficiency, thus initiating DNA damage and lipid peroxidation [14]. Lipid peroxidation (LPO) of membrane lipids are normally detected by enhanced levels of malondialdehyde (MDA) [15], a byproduct of LPO. MDA has been used as a biomarker for LPO because of its facile reaction with thiobarbituric acid using colorimetric assay. If we managed to verify the level of MDA increment with metal concentrations, we can suggest LPO as another quick and easy approach for monitoring of metals in fishes.

The objectives of the present study are: 1) to determine the concentration of metals $(\mathrm{Cd}, \mathrm{Cu}, \mathrm{Pb}$ and $\mathrm{Zn})$ in the tissues of tilapia, 2) to estimate the daily intake of metals by Malaysian, and 3) to determine the correlation between concentrations of metals and MDA levels in tissue as biomarker of lipid peroxidation due to metal pollution.

\section{Materials and Methods}

\section{Water parameters}

The water parameters in Tumpat lagoon and Terengganu River were measured using multiprobe Hydrolab Quanta. The temperature was found in the range of 30.9 to $32.6{ }^{\circ} \mathrm{C}$, dissolved oxygen of 2.70 to $7.52 \mathrm{mg} / \mathrm{L}$ and $\mathrm{pH}$ of 6.30 to 
7.41 in Tumpat lagoon. The smaller range of water parameter values was recorded in Terengganu River with temperature was in the range of 28.4 to $28.5^{\circ} \mathrm{C}$, and dissolved oxygen of 4.20 to $5.36 \mathrm{mg} / \mathrm{L}$ and pH of 7.52 to 8.55 . The water depth was deeper in Terengganu River than Tumpat lagoon with 1.6 to $3.4 \mathrm{~m}$ compared to 0.3 to $1.5 \mathrm{~m}$, respectively. Nevertheless, the major difference observed between these two sites was Tumpat lagoon has saline water with 29.7 to $30.4 \mathrm{ppt}$ while Terengganu river was a freshwater with a constant salinity of $0.02 \mathrm{ppt}$.

\section{Collection and preparation of tilapia}

Twenty individual of tilapia samples were collected randomly from each aquaculture farms, Tumpat lagoon and Terengganu River (Figure 1) within June to August 2016.

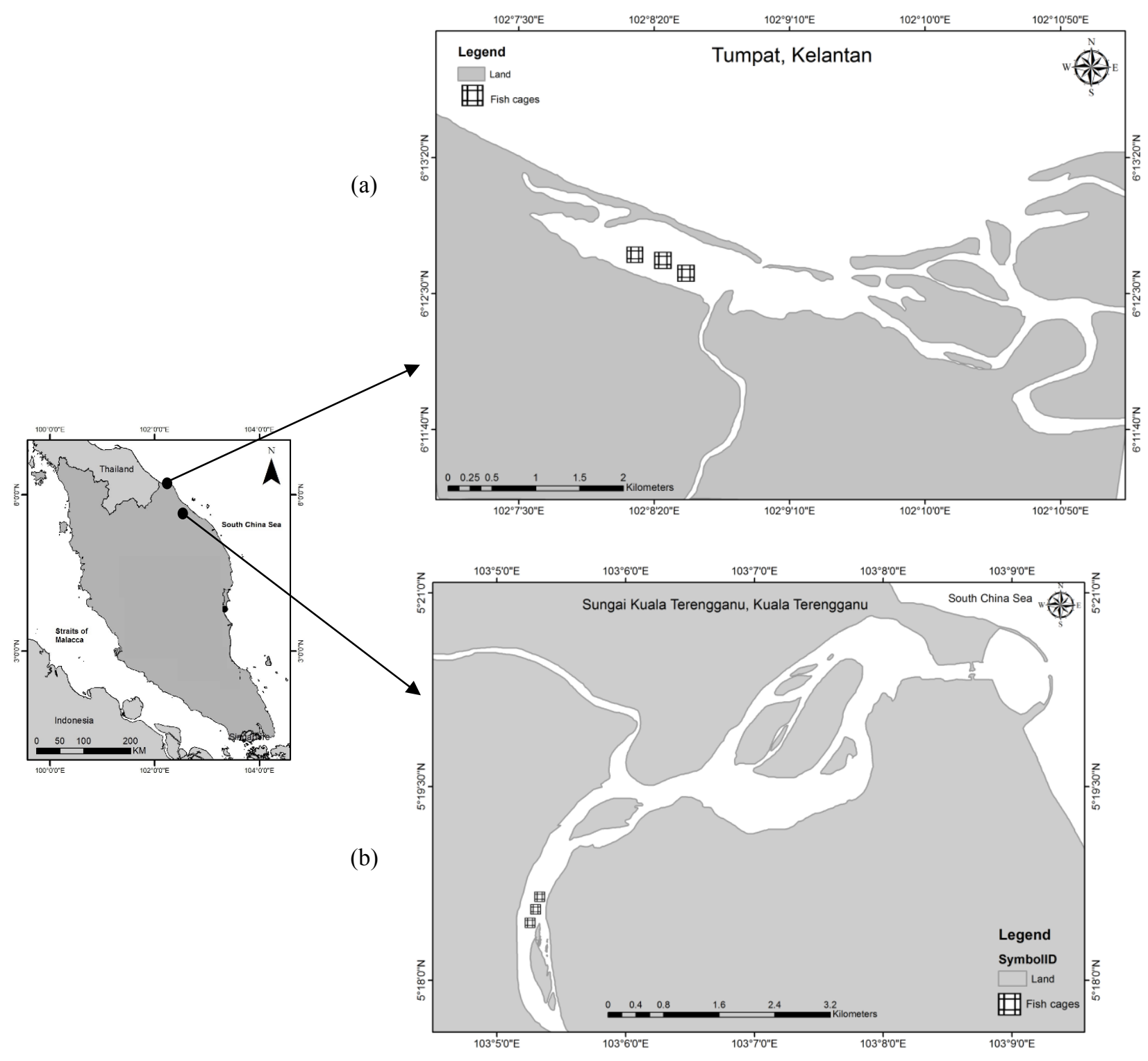

Figure 1. Twenty number of fresh tilapia were collected from (a) Tumpat lagoon, Kelantan and (b) Terengganu River, Terengganu 
The fishes were purchased alive and in fresh condition to maintain the quality of flesh and tissues for LPO analysis. Samples were kept cold in ice, transported to the laboratory and prepared at the same day of collection date. The body length and weight were measured prior to dissection to collect muscle, gill and liver tissues. Each muscle, gill and liver tissue samples were divided for metals and LPO analysis. Tissue samples for LPO were immediately stored under $-80{ }^{\circ} \mathrm{C}$ temperature condition to prevent deterioration of oxidative activities in the tissue. Glassware and apparatus used for metals analysis were soaked in $\mathrm{HNO}_{3} \quad 10 \%$ overnight and rinsed with double deionized water.

\section{Metals analysis}

Tissue samples for metal analysis were dried at $60{ }^{\circ} \mathrm{C}$ until constant weight was gained. Metal analysis was performed by using microwave system digestion as described in Türkmen [16] with some modifications. Targeted heavy metals in the tissues $(50 \mathrm{mg}$ ) were digested in Teflon vessel with $7 \mathrm{~mL}$ nitric acid and $1 \mathrm{~mL}$ hydrogen peroxide in maximum pressure of 100 bar at $300{ }^{\circ} \mathrm{C}$, closed digestion vessels (model - SK10, Milestone, Monroe, CT, USA). This device is able to extract ten samples simultaneously with high pressure rotor per batch. Upon completion of digestion (approximately 1 hour), the supernatant was thoroughly transferred into $10 \mathrm{~mL}$ polypropylene tube and meshed up to $10 \mathrm{~mL}$ with Milli-Q water. Samples were measured using inductively coupled plasma-mass spectrometry Perkin Elmer Elan 9000 (ICP-MS). The same procedures were applied to blank and standard reference material (SRM) samples, Dogfish Liver (DOLT-4). The detection limit for each heavy metal is shown in Table 1. The quality assurance test was performed using a standard reference material (Dogfish Liver, DOLT-4). Mean percentage recovery was calculated to be ranging from $81.3 \%$ to $98.7 \%$. Analysis were performed in four replicates $(n=6)$ with the error of all analysis within $\pm 25 \%$.

Table 1. Recovery test result of Dogfish Liver (DOLT-4) by ICP-MS in $\mu \mathrm{g} / \mathrm{g} d \mathrm{w}, \mathrm{n}=6$

\begin{tabular}{lcccc}
\hline Metal & Limit of Detection* & Certified value & Analysis value & Recovery (\%) \\
\hline $\mathrm{Cd}$ & 0.001 & $24.3 \pm 0.8$ & $21.8 \pm 0.03$ & 89.7 \\
$\mathrm{Cu}$ & 0.650 & $31.2 \pm 1.1$ & $30.8 \pm 6.19$ & 98.7 \\
$\mathrm{~Pb}$ & 0.068 & $0.16 \pm 0.04$ & $0.13 \pm 0.02$ & 81.3 \\
$\mathrm{Zn}$ & 9.090 & $116 \pm 6$ & $107 \pm 55.0$ & 92.2 \\
\hline
\end{tabular}

*Detection limit were estimated from standard curve of metals standard solution

\section{LPO analysis}

LPO activity was measured using lipid peroxidation (MDA) assay kit from Sigma-Aldrich, USA. The homogenization started with $10 \mathrm{mg}$ of respective tissue samples in $300 \mu \mathrm{L}$ of MDA lysis buffer saline with $3 \mu \mathrm{L}$ BHT (100x) on ice. The homogenized solution was then centrifuged at 13,000 $\mathrm{g} g$ for 10 minutes and the formed aliquot was transferred into micro centrifuge tube. The aliquot was added with $600 \mu \mathrm{L}$ of TBA solution and incubated at $95{ }^{\circ} \mathrm{C}$ for 60 minutes in MDA-TBA adduct. The determination of MDA in samples was done in 96well plates using ELISA plate spectrophotometer at $450 \mathrm{~nm}$ wavelength.

\section{Data analysis}

The condition factor of fish was calculated following Fulton's condition factor by dividing fish body weight ( $\mathrm{g}$ ) over [body length] ${ }^{3}(\mathrm{~cm})$ and multiplied to 100 . The daily intake by Malaysian people was computed by the multiplication of measured concentration by $160 \mathrm{~g}$ of average weight of fish consumed daily [17]. Statistical analysis was conducted using IBM SPSS Statistics 24. T-test was used to determine the significant difference of metal concentrations in two study sites, while Pearson correlation was employed to determine the correlation between metals and MDA values.

\section{Results and Discussion}

The weight, length and condition factor of tilapia from Tumpat lagoon were in the range of 360 to $800 \mathrm{~g}, 23.5$ to $35.0 \mathrm{~cm}$ and 2.23 to 2.98 , respectively. The weight, length and condition factor of tilapia from Terengganu River 
were found to be in the range of 250 to $498 \mathrm{~g}, 23.0$ to $28.0 \mathrm{~cm}$ and 1.78 to 2.72 , respectively. Condition factor values in these two sites were analysed but no significant difference was found $(p>0.05)$. Thus, environmental condition that influences the growth of tilapia in both sites was not much different from each other. The mean of moisture in respective muscle, gill and liver of tilapia were calculated as 63.5, 51.2 and 66.6\% in Tumpat lagoon; and 74.1, 64.1 and $62.8 \%$, in Terengganu River.

The concentration of $\mathrm{Cd}, \mathrm{Cu}, \mathrm{Pb}$ and $\mathrm{Zn}$ in respective muscles, gills and liver of tilapia is shown in Table 2. In general, the concentrations of all metals were found higher in gills and livers compared to muscles. The higher concentration in gills and livers could be explained by metallothionein's activities, a type of protein which has the ability to bind certain metals thus allowing these tissues to accumulate at a high degree [18]. The concentration of each metal was found significantly higher in Tumpat lagoon than Terengganu River (marked by asterisk) except for $\mathrm{Cu}$ in the liver. To our knowledge, no study has reported the level of pollutants in Tumpat lagoon. Therefore, no speculation could be made. From our observation, a sandbar has developed in front of the lagoon mouth, limiting the water movement especially during low tide. This was confirmed by the cage owner that some of the cultured fish normally died after this event. The limitation of water mixing and movement possibly retained metals in tilapia at extended period and higher level in Tumpat lagoon than Terengganu River. Copper concentration was extremely high in the liver of tilapia from both sites compared to muscles, suggested that liver as the best bioindicator of $\mathrm{Cu}$ accumulation.

The metals concentrations in this study are presented in both dry and wet weight in Table 2 to ease comparison with other reports. Cadmium concentrations in three different tissues from this study were lower than studies listed in Table 2. The concentration of $\mathrm{Cu}$ in muscles $(1.49 \pm 0.749$ and $1.60 \pm 0.736 \mu \mathrm{g} / \mathrm{g} \mathrm{dw})$ and gills $(2.10 \pm 0.749$ and $1.83 \pm 0.348 \mu \mathrm{g} / \mathrm{g} \mathrm{dw}$ ) in the current study was similar to values reported in River Benue with 1.65 and $2.98 \mu \mathrm{g} / \mathrm{g} \mathrm{dw}$, respectively [19]. The sampling location of River Benue received discharge wastes from various food industries such as Coca-cola PLC, Benue Breweries PLC plant and rice mills. This could attribute to the presence of such $\mathrm{Cu}$ level as the distance was only $12 \mathrm{~km}$ away from the sampling area. We could neither find distinguish food industry near Tumpat lagoon nor Terengganu River. The potential sources of metals were not investigated in the present study. However, we observed a small scale of scrap metal warehouse was located near Tumpat lagoon. Private motor vehicle workshop also operated near the lagoon where fishermen fix their boats engine and propeller potentially added the metals sources into the lagoon. A ship building dock and small jetties were found along Terengganu River, with boat wreck were left at the jetty without proper disposal. Hence, metals could potentially contribute from current boating activities as well as abandoned boat wreck [20]. Levels of $\mathrm{Pb}$ in the current study were higher than the concentrations reported in Shing Mun River, Hong Kong [21]. The Shing Mun River was claimed as one of the most contaminated river and estuarine region with two major industrial estates. However, no major industry could be traced either in Tumpat lagoon or Terengganu River. Therefore, $\mathrm{Pb}$ concentrations in tilapia in this study require further investigation as the levels were higher compared to the industrial area. However, $\mathrm{Zn}$ concentration in each tissue of this study was lower than the values reported in Jelebu, Malaysia [22]. The higher concentration reported in Jelebu was expected as that area was formerly a tin mining pool, and $\mathrm{Zn}$ was present since it is associated with $\mathrm{Al}$ [23].

Table 2. Comparison of metals concentration in muscle, gill and liver of tilapia, $\mu \mathrm{g} / \mathrm{g} \mathrm{dw}$ (unless noted as ww), to permissible level from established standards

\begin{tabular}{lcccccc}
\hline Study Area & Tissue & $\mathbf{C d}$ & $\mathbf{C u}$ & $\mathbf{P b}$ & $\mathbf{Z n}$ & Reference \\
\hline $\begin{array}{l}\text { Tumpat lagoon, } \\
\text { Malaysia }\end{array}$ & Muscle & $0.074 \pm 0.068$ & $1.49 \pm 0.749$ & $0.790 \pm 0.384$ & $15.2 \pm 3.75^{*}$ & This study \\
$(\mathrm{n}=20)$ & & $(\mathrm{ww}=0.047)$ & $(\mathrm{ww}=0.946)$ & $(\mathrm{ww}=0.502)$ & $(\mathrm{ww}=9.65)$ & \\
& Gill & $0.061 \pm 0.041$ & $2.10 \pm 0.749$ & $1.26 \pm 0.18^{*}$ & $52.5 \pm 14.5$ & \\
& & $(\mathrm{ww}=0.031)$ & $(\mathrm{ww}=1.08)$ & $(\mathrm{ww}=0.645)$ & $(\mathrm{ww}=26.9)$ & \\
& Liver & $0.395 \pm 0.129^{*}$ & $71.1 \pm 31.30^{*}$ & $2.14 \pm 0.451^{*}$ & $52.6 \pm 14.2$ & \\
& & $(\mathrm{ww}=0.263)$ & $(\mathrm{ww}=47.4)$ & $(\mathrm{ww}=1.43)$ & $(\mathrm{ww}=35.0)$ &
\end{tabular}


Nurulnadia et al: ASSESSMENT OF METALS CONCENTRATION IN TILAPIA (Oreochromis sp.) AND ESTIMATION OF DAILY INTAKE BY MALAYSIAN

Table 2 (cont'd). Comparison of metals concentration in muscle, gill and liver of tilapia, $\mu \mathrm{g} / \mathrm{g} \mathrm{dw}$ (unless noted as ww), to permissible level from established standards

\begin{tabular}{|c|c|c|c|c|c|c|}
\hline Study Area & Tissue & Cd & $\mathbf{C u}$ & $\mathbf{P b}$ & $\mathbf{Z n}$ & Reference \\
\hline \multirow{3}{*}{$\begin{array}{l}\text { Terengganu } \\
\text { River, Malaysia } \\
(\mathrm{n}=20)\end{array}$} & Muscle & $\begin{array}{c}0.048 \pm 0.036 \\
(w w=0.036)\end{array}$ & $\begin{array}{l}1.60 \pm 0.736 \\
(w w=1.19)\end{array}$ & $\begin{array}{l}0.567 \pm 0.319 \\
(w w=0.047)\end{array}$ & $\begin{array}{c}11.5 \pm 1.58^{*} \\
(\mathrm{ww}=0.420)\end{array}$ & \multirow[t]{3}{*}{ This study } \\
\hline & Gill & $\begin{array}{c}0.040 \pm 0.034 \\
(w w=0.026)\end{array}$ & $\begin{array}{l}1.83 \pm 0.348 \\
(w w=1.17)\end{array}$ & $\begin{array}{l}0.673 \pm 0.336^{*} \\
(w w=0.431)\end{array}$ & $\begin{array}{c}41.5 \pm 25.5 \\
(w w=26.6)\end{array}$ & \\
\hline & Liver & $\begin{array}{l}0.078 \pm 0.051^{*} \\
(w w=0.049)\end{array}$ & $\begin{array}{l}219 \pm 91.3^{*} \\
(\mathrm{ww}=138)\end{array}$ & $\begin{array}{l}0.671 \pm 0.453^{*} \\
(w w=0.421)\end{array}$ & $\begin{array}{c}43.7 \pm 17.3 \\
(w w=27.4)\end{array}$ & \\
\hline \multirow[t]{3}{*}{ Jelebu, Malaysia } & Muscle & na & $1.20 \pm 0.100$ & $0.048 \pm 0.007$ & $17.5 \pm 0.800$ & \multirow[t]{3}{*}[22]{} \\
\hline & Gill & na & $1.90 \pm 0.100$ & $0.402 \pm 0.070$ & $64.3 \pm 3.00$ & \\
\hline & Liver & na & $0.007 \pm 0.001$ & $0.20 \pm 0.02$ & $85.0 \pm 6.00$ & \\
\hline \multirow{2}{*}{$\begin{array}{l}\text { River Benue, } \\
\text { Nigeria }\end{array}$} & Muscle & 0.306 & 1.65 & 1.18 & 5.24 & \multirow[t]{2}{*}{ [19] } \\
\hline & Gill & 0.351 & 2.98 & 1.00 & 7.15 & \\
\hline \multirow{2}{*}{$\begin{array}{l}\text { Fo Tan River, } \\
\text { Hong Kong }\end{array}$} & Muscle & $0.540 \pm 0.190$ & $2.09 \pm 0.56$ & $1.53 \pm 0.55$ & $22.4 \pm 1.50$ & \multirow[t]{2}{*}[24]{} \\
\hline & Gill & $1.76 \pm 0.130$ & $77.8 \pm 6.60$ & $11.0 \pm 1.20$ & $77.8 \pm 6.60$ & \\
\hline \multirow{3}{*}{$\begin{array}{l}\text { Shing Mun River, } \\
\text { Hong Kong (ww) }\end{array}$} & Muscle & $0.016 \pm 0.009$ & $0.240 \pm 0.090$ & $0.247 \pm 0.163$ & $17.8 \pm 3.60$ & \multirow[t]{3}{*}[21]{} \\
\hline & Gill & $0.049 \pm 0.020$ & $11.3 \pm 8.28$ & $0.380 \pm 0.150$ & $26.7 \pm 8.80$ & \\
\hline & Liver & $0.393 \pm 0.173$ & $328 \pm 181$ & $0.455 \pm 0.168$ & $38.4 \pm 9.80$ & \\
\hline $\begin{array}{l}\text { Mguza Dam, } \\
\text { Zimbabwe (ww) }\end{array}$ & & $0.120 \pm 0.020$ & $0.130 \pm 0.040$ & $0.430 \pm 0.040$ & $1.23 \pm 0.140$ & {$[25]$} \\
\hline \multicolumn{7}{|l|}{ Permissible level } \\
\hline \multicolumn{2}{|c|}{$\begin{array}{l}\text { Department of Health, New } \\
\text { Zealand }\end{array}$} & 1.00 & 30.0 & 2.00 & 40.0 & {$[26]$} \\
\hline \multicolumn{2}{|c|}{$\begin{array}{l}\text { Department of Health, } \\
\text { Australia }\end{array}$} & 0.200 & 10.0 & 1.50 & 150 & {$[26]$} \\
\hline \multicolumn{2}{|c|}{$\begin{array}{l}\text { Turkish permissible limit } \\
\text { (body weight) }\end{array}$} & 0.100 & 20.0 & 1.00 & 50.0 & {$[27]$} \\
\hline \multicolumn{2}{|c|}{ World Health Organization } & na & 30.0 & na & 2.00 & {$[28]$} \\
\hline \multicolumn{2}{|c|}{$\begin{array}{l}\text { Malaysia Food Regulation } \\
\text { (ww) }\end{array}$} & 1.00 & na & 2.00 & na & [29] \\
\hline
\end{tabular}

na = not available; $\mathrm{dw}=$ dry weight; $\mathrm{ww}=$ wet weight; The asterisk indicates the significant difference between two study sites $(\mathrm{p}<0.05)$.

The comparisons were made with several studies to provide us important information of status of metals accumulation in this study compared to other sites. However, this would not be enough to justify if the level is safe for human consumption. Therefore, permissible levels from several standards were referred. Comparing to the Malaysia Food Regulation [29], $\mathrm{Cd}$ and $\mathrm{Pb}$ in tilapia in this study were below the permissible level, suggesting that the fish is safe for consumption. Since the permissible values are not available for $\mathrm{Cu}$ and $\mathrm{Zn}$ in Malaysia Food Regulation, the other values were referred [26, 27, 28]. Copper level in the muscles and gills of tilapia were lower than all permissible values except for liver in both Tumpat lagoon and Terengganu River. Concerning with human consumption, livers are normally discarded prior to cooking. Hence, they will not impose any risk to humans. 
Zinc concentration in all three tissues in this study extremely exceeded the permissible values of World Health Organization [28], but lower than permissible value of Department of Health Australia [26]. The concentration of $\mathrm{Zn}$ in gills and muscles from Tumpat lagoon exceeded Turkish permissible level [27] while Zn concentration in Terengganu River exceeded the Department of Health New Zealand [26]. Consequently, Zn content in tilapia should be monitored as the level has exceeded permissible level of these established standards. Zinc is one of the essential elements with the ability to function as an antioxidant and stabilize membranes especially in preventing free radical which induces injury during inflammatory processes [30]. However, the excess of $\mathrm{Zn}$ accumulation in human body can lead to local neuronal deficits, epigastric pain, diarrhea and elevated risk of prostate cancer [31].

Besides Malaysia Food Regulation, Malaysian government has not established the maximum permitted level of metals in fish. Therefore, standard values from Food Standards Australia and New Zealand (FSANZ) and Joint Expert Committee on Food Additives (JECFA) were referred to estimate the amount of daily consumption in humans [17] as shown in Table 3. The determination of seafood ingested per week is based on Laurenti [32] where author claimed the fish consumption in Malaysia is as high as $57.7 \mathrm{~kg} /$ year. This gives out an average estimation of $1.11 \mathrm{~kg} /$ week or approximately $160 \mathrm{~g} /$ day of fish consumed by Malaysian people. The daily intake by Malaysian people was computed by the multiplication of measured concentration by $160 \mathrm{~g}$ of average weight of fish consumed daily [17]. Comparing this to Malaysia Food Regulation, the daily intake of $\mathrm{Cd}$ and $\mathrm{Pb}$ were lower than the maximum permitted levels. The concentration level of $\mathrm{Cu}$ and $\mathrm{Zn}$ in this study was also lower than the standard value, except for $\mathrm{Cu}$ in the livers. Hence, as long as they do not ingest the livers, tilapia from this study are safe for consumption.

Table 3. Summary of dietary intakes for measured metals with daily consumption of $160 \mathrm{~g}$ of tilapia and comparison with food standards

\begin{tabular}{|c|c|c|c|c|c|}
\hline & & Cd & $\mathbf{C u}$ & $\mathbf{P b}$ & $\mathbf{Z n}$ \\
\hline \multirow[t]{4}{*}{ Standards } & FSANZ RDI (mg/day) ${ }^{\mathrm{a}}$ & na & 3.00 & na & 12 \\
\hline & FSANZ ML $(\mathrm{mg} / \mathrm{kg})^{\mathrm{a}}$ & na & 5.00 & 0.500 & 130 \\
\hline & JECFA (mg/day $)^{\mathrm{a}}$ & na & 30.0 & 3.6 & 1000 \\
\hline & Malaysia Food Regulation ${ }^{\mathrm{b}}$ & 0.159 & na & 0.317 & na \\
\hline \multirow[t]{8}{*}{ Measured concentration $(\mu \mathrm{g} / \mathrm{g} w w)$} & Tumpat lagoon & & & & \\
\hline & Muscle & 0.047 & 0.946 & 0.502 & 9.65 \\
\hline & Gill & 0.031 & 1.08 & 0.645 & 26.9 \\
\hline & Liver & 0.263 & 47.4 & 1.43 & 35.0 \\
\hline & Terengganu River & & & & \\
\hline & Muscle & 0.036 & 1.19 & 0.047 & 0.420 \\
\hline & Gill & 0.026 & 1.17 & 0.431 & 26.6 \\
\hline & Liver & 0.049 & 138 & 0.421 & 27.4 \\
\hline \multirow[t]{8}{*}{ Intake (mg/day) } & Tumpat lagoon & & & & \\
\hline & Muscle $^{\mathrm{a}}$ & 0.008 & 0.150 & 0.080 & 1.53 \\
\hline & Gill $^{\mathrm{a}}$ & 0.005 & 0.171 & 0.102 & 4.69 \\
\hline & Liver & 0.042 & 7.52 & 0.227 & 5.55 \\
\hline & Terengganu River & & & & \\
\hline & Muscle $^{\mathrm{a}}$ & 0.006 & 0.189 & 0.008 & 0.067 \\
\hline & Gill $^{\mathrm{a}}$ & 0.004 & 0.186 & 0.068 & 4.22 \\
\hline & Liver $^{\mathrm{a}}$ & 0.008 & 21.9 & 0.067 & 4.35 \\
\hline
\end{tabular}

na $=$ not available; ${ }^{a}$ Values referred from [27]; ${ }^{\mathrm{b}}$ calculated to daily consumption of $160 \mathrm{~g}$ tilapia; bold values indicate the value exceeding standards regulation 
Biochemical endpoints have been employed to find the correlation between the metal bioaccumulation and stress level in fish $[33,34]$. This technique is useful to recognize and identify subtle and early effects of contaminants [33, $35,36]$. LPO is one of the stress indicators formed from the oxidative deterioration of polyunsaturated lipids in the cell membranes and organelles. Malondialdehyde (MDA) is a LPO byproduct, generally used as a sign of cellular injuries [37]. Among these studied metals, $\mathrm{Cu}$ is most likely to enhance LPO as $\mathrm{Cu}$ will readily cycle between the cupric $\left(\mathrm{Cu}^{2+}\right)$ and the cuprous $\left(\mathrm{Cu}^{2+}\right)$ oxidation states, an activity that associated with the generation of hydroxyl radicals $(. \mathrm{OH})[35,38]$. In the current study, LPO was measured in each tissue through the MDA values to see their correlation to metal concentrations. Since high concentrations of $\mathrm{Cu}$ were measured in the liver of tilapia from both sites, high concentrations of MDA in the liver was expected. The MDA values in the liver of tilapia from Tumpat lagoon results seem to support the assumption but the calculated values in Terengganu River was not as expected (Table 4).

Pearson correlation also justified low correlation between metals in tissues to the MDA values (Table 4). Despite of that, previous studies have reported increases in LPO with increasing metal exposure in fish [39, 40, 41]. Their investigation was performed in the laboratory exposure experiment, hence they can conclude in a better picture of metal concentrations and inductions of LPO. The measurement of LPO in the current study could be influenced by various factors such as tidal patterns, weather conditions, and sewage effluent as the fish was collected from the field and analysed right away in the laboratory. Therefore, in order to clearly identify the LPO as a bioindicator of metal pollution, a laboratory experiment should be conducted in the near future.

Table 4. Pearson correlation of metals and MDA in muscle, gill and liver of tilapia from Tumpat lagoon and Terengganu River

\begin{tabular}{lccc}
\hline Tumpat Lagoon & $\begin{array}{c}\text { MDA Muscle } \\
(\mathbf{0 . 0 6 8} \pm \mathbf{0 . 0 2 6} \text { nmole } / \boldsymbol{\mu L})\end{array}$ & $\begin{array}{c}\text { MDA gill } \\
\mathbf{( 0 . 8 9 4} \pm \mathbf{0 . 3 6 5} \text { nmole } / \boldsymbol{\mu L})\end{array}$ & $\begin{array}{c}\text { MDA liver } \\
\mathbf{( 1 . 1 2} \pm \mathbf{0 . 5 2 4} \mathbf{~ n m o l e} / \boldsymbol{\mu L})\end{array}$ \\
\hline $\mathrm{Cd}$ & -0.279 & 0.625 & -0.597 \\
$\mathrm{Cu}$ & 0.106 & 0.304 & -0.405 \\
$\mathrm{~Pb}$ & -0.123 & 0.052 & 0.122 \\
$\mathrm{Zn}$ & 0.037 & 0.002 & 0.363 \\
\hline \multirow{2}{*}{ Terengganu River } & MDA muscle & MDA gill & MDA liver \\
& $\mathbf{( 0 . 0 3 1} \pm \mathbf{0 . 0 2 8}$ nmole $/ \boldsymbol{\mu L})$ & $\mathbf{( 0 . 0 7 4} \pm \mathbf{0 . 0 5 0}$ nmole $/ \boldsymbol{\mu L})$ & $\mathbf{( 0 . 0 8 5} \pm \mathbf{0 . 0 2 9}$ nmole $/ \boldsymbol{\mu L})$ \\
\hline $\mathrm{Cd}$ & $0.699^{*}$ & -0.006 & -0.236 \\
$\mathrm{Cu}$ & 0.285 & -0.038 & -0.248 \\
$\mathrm{~Pb}$ & -0.074 & 0.003 & 0.582 \\
$\mathrm{Zn}$ & -0.173 & -0.007 & $0.740^{*}$ \\
\hline
\end{tabular}

*Significant at $\alpha=0.05$; bold font indicates moderate correlation

\section{Conclusion}

The concentration of $\mathrm{Cd}, \mathrm{Cu}, \mathrm{Pb}$ and $\mathrm{Zn}$ were consistently higher in the gills and livers than muscle tissues of tilapia from both Tumpat lagoon and Terengganu River. This indicates their ability to accumulate those metals. Compared to the established permissible level, the concentration of studied metals was low except for $\mathrm{Zn}$ concentration in the livers. However, liver normally discarded before cooking and not consumed by local people. The estimation of daily intake also concludes that tilapia is safe for consumption as long as liver is removed from their meal. Copper and $\mathrm{Pb}$ concentrations in tilapia were comparable to tilapia collected from industrial area, hence continuous monitoring should be done as part of environment and human safety. The LPO activity was measured in each tissue to represent biological effects in fish. Pearson correlation showed inconsistent correlation between MDA, byproduct of LPO to metals concentration, hence not a suitable indicator of metals concentrations in the current study. This could 
possibly due to various factors that lead to oxidative stress in natural conditions. Therefore, to clearly justify the induction of LPO in fish due to metals accumulation, a control laboratory experiment should be carried out as it is previously proven as a good biomarker for metals.

\section{Acknowledgements}

The present study was funded by Research Acculturation Grant Scheme $(\boldsymbol{R} A \boldsymbol{G S})$, Ministry of Higher Education, Malaysia.

\section{References}

1. Ng, W. K., and Romano, N. (2013). A review of the nutrition and feeding management of farmed tilapia throughout the culture cycle. Reviews in Aquaculture, 5(4): 220-254.

2. Food and Agriculture Organization of the United Nations (2011). FISHSTAT plus: Universal Software for Fishery Statistical Time Series, Version 2.3. FAO Fisheries Department, Fishery Information, Data and Statistical Unit, Rome.

3. Yusoff, A. (2015). Status of resource management and aquaculture in Malaysia. In M. R. R. Romana-Eguia, F. D. Parado-Estepa, N. D. Salayo and M. J. H. Lebata-Ramos (Eds.), Resource Enhancement and Sustainable Aquaculture Practices in Southeast Asia: Challenges in Responsible Production of Aquatic Species: Proceedings of the International Workshop on Resource Enhancement and Sustainable Aquaculture Practices in Southeast Asia 2014 (RESA) Tigbauan, Iloilo, Philippines: Aquaculture Dept., Southeast Asian Fisheries Development Center: pp. 53-65.

4. El-Sayed, A. F. M. (1999). Alternative dietary protein sources for farmed tilapia, Oreochromis spp. Aquaculture, 179: 149-168.

5. Ferreira, M., Caetano, M., Costa, J., Pousão-Ferreira, P., Vale, C. and Reis-Henriques, M. A. (2008). Metal accumulation and oxidative stress responses in, cultured and wild, white seabream from Northwest Atlantic. Science of the Total Environment, 407(1): 638-646.

6. Luoma, S. N., and Rainbow, P. S. (2008). Sources and cycles of trace metals. In: Metal Contamination in Aquatic Environments: Science and Lateral Management. Cambridge University Press, Cambridge: pp. 47-66.

7. Alam, M. G. M., Tanaka, A., Stagnitti, F., Allinson, G., and Maekawa, T. (2001). Observations on the effects of caged carp culture on water and sediment metal concentrations in Lake Kasumigaura, Japan. Ecotoxicology and Environmental Safety, 48: 107-115.

8. Pelgrom, S. M. G. J., Lamers, L. P. M., Garritsen, J. A. M., Pels, B. M., Lock, R. A. C., Balm, P. H. M., and Bonga, S. W. (1994). Interactions between copper and cadmium during single and combined exposure in juvenile tilapia Oreochromis mossambicus: Influence of feeding condition on whole body metal accumulation and the effect of the metals on tissue water and ion content. Aquatic Toxicology, 30(2): 117-135.

9. Young, R. A. (2005). Toxicity profiles: Toxicity summary for cadmium, risk assessment information system, RAIS, University of Tennessee. Access from rais.ornl.gov/tox/profiles/cadmium.shtml.

10. Nolan, K. R. (1983). Copper toxicity syndrome. Journal of Orthomolecular Psychiatry, 12(4): 270-282.

11. Cheung, A. P., Lam, T. H. J., and Chan, K. M. (2004). Regulation of Tilapia metallothionein gene expression by heavy metal ions. Marine Environmental Research, 58(2-5): 389-394.

12. Wong, C. K. C., Yeung, H. Y., Cheung, R. Y. H., Yung, K. K. L. and Wong, M. H. (2000). Ecotoxicological assessment of persistent organic and heavy metal contamination in Hong Kong coastal sediment. Archives of Environmental Contamination and Toxicology, 38(4): 486-493.

13. Souid, G., Souayed, N., Yaktiti, F. and Maaroufi, K. (2013). Effect of acute cadmium exposure on metal accumulation and oxidative stress biomarkers of Sparusaurata. Ecotoxicology and Environmental Safety, 89: 17.

14. Van der Oost, R., Beyer, J. and Vermeulen, N. P. E. (2003). Fish bioaccumulation and biomarkers in environmental risk assessment: A review. Environmental Toxicology and Pharmacology, 13: 57-149.

15. Gravato, C., Teles, M., Oliveira, M. and Santos, M. A. (2006). Oxidative stress, liver biotransformation and genotoxic effects induced by copper in Anguilla anguilla L. - the influence of pre-exposure to [beta]naphthoflavone. Chemosphere, 65: 1821-1830.

16. Türkmen, A., Türkmen, M., Tepe, Y. and Akyurt, I. (2005). Heavy metals in three commercially valuable fish species from Iskenderun Bay, Northern East Mediterranean Sea, Turkey. Food Chemistry, 91(1): 167-172. 
17. Allinson, G., Salzman, S. A., Turoczy, N., Nishikawa, M., Amarasinghe, U. S., Nirbadha, K. G. S. and De Silva, S. S. (2009). Trace metal concentrations in Nile tilapia (Oreochromisniloticus) in three catchments, Sri Lanka. Bulletin of Environmental Contamination and Toxicology, 82(3): 389-394.

18. Visnjic-Jeftic, Z., Jaric, I., Jovanovic, L., Skoric, S., Smederevac-Lalic, M., Nikcevic, M. and Lenhardt, M. (2010). Heavy metal and trace element accumulation in muscle, liver and gills of the Pontic shad (Alosaimmaculata Bennet 1835) from the Danube River (Serbia). Microchemical Journal, 95(2): 341-344.

19. Eneji, I. S., Sha'Ato, R. and Annune, P. A. (2011). Bioaccumulation of heavy metals in Fish (Tilapia zilli and Clariasgariepinus) organs from River Benue, North-Central Nigeria. Pakistan Journal of Analytical and Environmental Chemistry, 12: 1-8.

20. Reddy, M. S., Basha, S., Kumar, V. S., Joshi, H. V. and Ramachandraiah, G. (2004). Distribution, enrichment and accumulation of heavy metals in coastal sediments of Alang-Sosiya ship scrapping yard, India. Marine Pollution Bulletin, 48(11-12): 1055-1059.

21. Shen, L. H., Lam, K. L., Ko, P. W. and Chan, K. M. (1998). Metal concentrations and analysis of metal binding protein fractions from the liver of tilapia collected from Shing Mun River. Marine Environmental Research, 46(1-5): 597-600.

22. Low, K. H., Zain, S. M., and Abas, M. R. (2011). Evaluation of metal concentrations in red tilapia (Oreochromis spp) from three sampling sites in Jelebu, Malaysia using principal component analysis. Food Analytical Methods, 4(3): 276-285.

23. Wang, S., Ang, H. M., and Tadé, M. O. (2008). Novel applications of red mud as coagulant, adsorbent and catalyst for environmentally benign processes. Chemosphere, 72(11): 1621-1635.

24. Zhou, H. Y., Cheung, R. Y. H., Chan, K. M. and Wong, M. H. (1998). Metal concentrations in sediments and Tilapia collected from inland waters of Hong Kong. Water Research, 32(11): 3331-3340.

25. Siwela, A. H., Nyathi, C. B., and Naik, Y. S. (2009). Metal accumulation and antioxidant enzyme activity in $C$. gariepinus, Catfish, and O. mossambicus, tilapia, collected from lower Mguza and Wright Dams, Zimbabwe. Bulletin of Environmental Contamination and Toxicology, 83(5): 648.

26. Food and Agriculture Organization of the United Nations (1983). Food and Agriculture Organisation. Circular no. 764. Rome.

27. TKB, Central Fisheries Research Institute (2002). Fisheries laws and regulations. Ministry of Agriculture and Rural Affairs, Conservation and Control General Management. Ankara, Turkey.

28. World Health Organization (1989) Environment health criteria. Heavy metals environmental aspects. World Health Organization, Geneva.

29. Alina, M., Azrina, A., Mohd Yunus, A. S., Mohd Zakiuddin, S., Mohd Izuan Effendi, H. and Muhammad Rizal, R. (2012). Heavy metals (mercury, arsenic, cadmium, plumbum) in selected marine fish and shellfish along the Straits of Malacca. International Food Research Journal, 19(1): 135-140.

30. Prasad, A. S. (2008). Zinc in human health: effect of zinc on immune cells. Molecular Medicine, 14(5-6): 353.

31. Plum, L. M., Rink, L., and Haase, H. (2010). The essential toxin: impact of zinc on human health. International Journal of Environmental Research and Public Health, 7(4), 1342-1365.

32. Laurenti, G. (2002). Fish and fishery products: world apparent consumption statistics based on food balance sheets. FAO Fisheries Circular 2002 No. 821, rev. 6. 1961-1999.

33. Vasseur, P. and Cossu-Leguille, C. (2003). Biomarkers and community indices as complementary tools for environmental safety. Environmental International, 28: 711-717.

34. Giguère, A., Campbell, P. G., Hare, L., and Cossu-Leguille, C. (2005). Metal bioaccumulation and oxidative stress in yellow perch (Percaflavescens) collected from eight lakes along a metal contamination gradient $(\mathrm{Cd}$, $\mathrm{Cu}, \mathrm{Zn}, \mathrm{Ni}$ ). Canadian Journal of Fisheries and Aquatic Sciences, 62(3): 563-577.

35. Di Giulio, R. T., Washburn, P. C., Wenning, R. J., Winston, G. W. and Jewell, C. S. (1989). Biochemical responses in aquatic animals: A review of determinants of oxidative stress. Environmental Toxicology and Chemistry, 8(12): 1103-1123.

36. Stegeman, J. J., Brouwer, M., Di Giulio, R. T., Förlin, L., Fowler, B. A., Sanders, B. M. and Van Veld, P. A. (1989). Molecular responses to environmental contamination: enzyme and protein synthesis as indicators of chemical exposure and effect. In Biomarkers. Edited by R. J. Hugget, R. A. Kimerle, P. M. J. Mehrle, and H. L. Bergman. Lewis Publishers, Boca Raton. pp. 235-333. 
37. Christie, N. T. and Costa, M. (1984). In vitro assessment of the toxicity of metal compounds. IV. Disposition of metals in cells: interactions with membranes, glutathione, metallothionein, and DNA. Biological Trace Element Research, 6: 139-158.

38. Halliwell B. and Gutteridge J. M. C. (1984) Oxygen toxicity, oxygen radicals, transition metals and disease. Biochemical Journal, 219: 1-14.

39. Chaurasia, S. S. and Kar, A. (1999). An oxidative mechanism for the inhibition of iodothyronine 5'monodeiodinase activity by lead nitrate in the fish, Heteropneustesfossilis. Water Air and Soil Pollution 111: 417-423.

40. Romeo, M., Bennani, N., Gnassia-Barelli, M., Lafaurie, M. and Girard, J. P. (2000). Cadmium and copper display different responses towards oxidative stress in the kidney of the sea bass Dicentrarchuslabrax. Aquatic Toxicology, 48: 185-194.

41. Ptashynski, M. D., Pedlar, R. M., Evans, R. E., Wautier, K. G., Baron, C. L. and Klaverkamp, J. F. (2001). Accumulation, distribution and toxicology of dietary nickel in lake white fish (Coregonusclupeaformis) and lake trout (Salvelinusnamaycush). Comparative Biochemistry and Physiology Part C: Toxicology and Pharmacology, 130: 145-162. 